\section{Susceptibility of Selected Cherry Clones and Related Species to Western X-Disease}

\author{
Jerry K. Uyemoto', Bruce C. Kirkpatrick \\ University of California, Davis, CA 95616
}

\author{
James N. Cummins ${ }^{3}$ \\ New York State Agricultural Experiment Station, Cornell University, \\ Geneva, NY 14456
}

Additional index words. X-disease mycoplasma, Prunus spp., rootstock screening

\begin{abstract}
Prunus species, advanced rootstock selections, and named cherry cultivars and rootstock were bud-inoculated with the Western X-disease mycoplasma-like organism (X-MLO) and evaluated for host responses. Most accessions inoculated were susceptible to the X-MLO. Individuals from the species $P$. mahaleb L., $P$. maackii Rupr., P. serotina J.F. Ehrh., P. serrulata Lindl., and $P$. subhirtella Miq. did not become infected with the X-MLO despite being grafted on infected rootstock.
\end{abstract}

Prunus taxons respond variously to infection with the Western X-MLO (Gilmer and B1odgett, 1976). Under natural conditions, when X-MLO infection occurs via phloemfeeding leafhopper vectors, cherry scions grown on mazzard ( $P$. avium L.) rootstock decline slowly, with obvious symptoms occurring by the 2 nd year following inoculation. Infected tart cherry ( $P$. cerasus L.) and sweet cherry $(P$. avium) trees have sparsely foliated canopies whose limbs bear small leaves and small, pointed, greenish-white to pale-red cherries. In contrast, infected cherry scions on $P$. mahaleb rootstock decline rapidly and generally die within a year after inoculation; leaf and fruit symptoms are therefore often absent. The mahaleb rootstock is considered "resistant" because, when it is multiple-grafted with susceptible scion buds, the X-MLO infection is restricted to the inoculated shoot; other scion shoots arising from separate buds on the same mahaleb rootstock remain free of the X-MLO (Richards and Cochran, 1957).

Several rootstock candidates have been introduced recently, and some are ready for commercialization. These comprise several species and interspecific hybrids whose response to X-MLO infection was unknown. Our study was undertaken to examine the responses of currently used and new rootstock and Prunus spp. to infection by the

Received for publication 15 Mar. 1991. We gratefully acknowledge financial support received from San Joaquin Cherry Growers and Industries Foundation, Stockton, Calif.; from International Dwarf Fruit Tree Assn.; from New York Cherry Growers Assn.; Victor, N. Y.; and from the USDA Clonal Germplasm Repository, Davis, Calif., through Cooperative Agreement 58-91H2-6-45. The cost of publishing this paper was defrayed in part by the payment of page charges. Under postal regulations, this paper therefore must be hereby marked advertisement solely to indicate this fact.

'Research Plant Pathologist, USDA-ARS.

${ }^{2}$ Assistant Professor of Plant Pathology.

${ }^{3}$ Professor of Pomology.
X-MLO. Also included were named cherry scion cultivars and rootstock.
Several nursery rows of mazzard seedlings, free of the common seedborne viruses Prunus necrotic ringspot and prune dwarf, were planted at the Univ. of California, Davis, in Feb. 1987. During Aug. 1987, buds of each accession were grafted on 10 mazzard seedlings at $\approx 50 \mathrm{~cm}$ above the soil line. The accessions were derived from breeding programs at Giessen, Germany (GI series); Geneva, N.Y. (G series); and Gembloux, Belgium (GM series); also included were other accessions of interest obtained from the IR2 program in Presser, Wash. (WA series) and Foundation Plant Materials Service, Univ. of California, Davis. A total of 76 accessions was evaluated. Rootstock suckers were maintained so that they also could be sampled and tested by dot-blot assays.

About 1 year following shoot growth and development of the accessions, three X-MLO inoculum chips per tree were T-budded into the mazzard rootstock portion of each of one to four trees per accession. The number inoculated depended on the total number of trees available per accession. An equal number of trees per accession served as uninoculated controls. The inocula were derived from
Table 1. Cherry cultivars, rootstocks and species susceptible to infection by the Western X-disease mycoplasma-like organism

\begin{tabular}{|c|c|c|c|}
\hline Accession $^{2}$ & $\begin{array}{l}\text { No. scions infectedy } \\
\text { /no. plants inoculated }\end{array}$ & Accession & $\begin{array}{l}\text { No. scions inf } \\
\text { no. plants ino }\end{array}$ \\
\hline \multicolumn{4}{|c|}{ Prunus avium } \\
\hline Big Burlat & $2 / 2$ & Napoleon & $1 / 2$ \\
\hline Bing & $1 / 1$ & Stella & $2 / 2$ \\
\hline Black Tartarian & $1 / 2$ & Utah Giant & $2 / 2$ \\
\hline Canindex & $1 / 1$ & Van & $2 / 2$ \\
\hline $\mathrm{F} 12 / 1$ & $3 / 4$ & & \\
\hline \multicolumn{4}{|c|}{ Prunus cerasus $\mathbf{x}^{\mathbf{x}}$} \\
\hline CAP 6P & $2 / 2$ & Montmorency & $1 / 2$ \\
\hline CAB 9E & $2 / 2$ & Northstar & $2 / 2$ \\
\hline English Morello & $3 / 4$ & Schattenmorello & $2 / 2$ \\
\hline Kansas Sweet & $1 / 2$ & Stockton Morello & $3 / 4$ \\
\hline Krassa Severa & $2 / 2$ & Vladimir 242 & $1 / 2$ \\
\hline Meteor & $3 / 4$ & & \\
\hline \multicolumn{4}{|c|}{ Prunus fruticosa $a^{x}$} \\
\hline FR-4 & $2 / 2$ & FR-8 & $1 / 2$ \\
\hline FR-6 & $4 / 4$ & WA-6 & $1 / 2$ \\
\hline \multicolumn{4}{|c|}{ Prunus avium $\times$ P. canescens Bois. ${ }^{\mathbf{X}}$} \\
\hline Gisela (Gi.) 196/4 & $3 / 4$ & Gi. $196 / 13$ & $2 / 2$ \\
\hline \multicolumn{4}{|c|}{ Prunus avium $\times$ P. fruticosa } \\
\hline G448 ${ }^{\mathrm{x}}$ & $4 / 4$ & G9967 & $2 / 2$ \\
\hline G8995x & $3 / 4$ & Gi. $172 / 3$ & $2 / 2$ \\
\hline G9965 & $2 / 2$ & Gi. $172 / 7$ & $4 / 4$ \\
\hline \multicolumn{4}{|c|}{ Prunus canescens $\times$ P. cerasus ${ }^{\mathbf{x}}$} \\
\hline Gi. $148 / 1$ & $2 / 2$ & Gi. $195 / 1$ & $4 / 4$ \\
\hline Gi. $148 / 2$ & $3 / 4$ & Gi. $195 / 2$ & $4 / 4$ \\
\hline Gi. $148 / 8$ & $4 / 4$ & & \\
\hline \multicolumn{4}{|c|}{ P. cerasus $\times$ P. fruticosa } \\
\hline Gi. $154 / 4^{x}$ & $3 / 4$ & Gi. $173 / 9$ & $3 / 4$ \\
\hline Gi. $154 / 7$ & $1 / 2$ & Oppenheim & $2 / 4$ \\
\hline \multicolumn{4}{|c|}{ Other Prunus spp. } \\
\hline$P$. cartilagena & & & $1 / 2$ \\
\hline P. dawykensis ${ }^{\mathbf{x}}$ & & & $2 / 2$ \\
\hline P. dawykensis cv. & $61 / 1$ & & $1 / 2$ \\
\hline$P$. sargentii Rehd. & WA $13^{x}$ & & $2 / 2$ \\
\hline P. $\times$ schmittii & & & $3 / 4$ \\
\hline P. serrulata Lindl. & Albaplena ${ }^{\mathbf{x}}$ & & $1 / 2$ \\
\hline$P$. avium $\times$ P pseit & rasus Lindl. cv. Colt & & $2 / 2$ \\
\hline P. spp. cv. Birch $\mathrm{E}$ & & & $2 / 2$ \\
\hline
\end{tabular}

${ }^{2}$ Accessions were propagated on mazzard seedlings; all X-MLO inoculations were confined to the mazzard portion of the tree.

${ }^{y}$ Extracts of scion leaf-petioles were positive for X-MLO DNA by dot-blot assays.

xplants exhibited yellow or bronzed leaves. 
Table 2. Cherry cultivars, rootstocks, and species resistant to Western $\mathrm{X}$-disease mycoplasma-like organism, testing negative for the presence of X-MLO when mazzard rootstocks were X-MLO positive.

\begin{tabular}{|c|c|}
\hline Accession $^{2}$ & $\begin{array}{l}\text { No. mazzard } \\
\text { rootstocks infected/ } \\
\text { no. trees inoculated }\end{array}$ \\
\hline $\begin{array}{l}\text { Prunus maackil y } \\
\text { P. mahaleb }\end{array}$ & $1 / 2$ \\
\hline Glenn Dale \#4y & $1 / 2$ \\
\hline WA-10 & $1 / 2$ \\
\hline WA\#916 & $1 / 4$ \\
\hline $\begin{array}{l}P . \text { serotina } \mathrm{cv} . \mathrm{WA}-15^{\mathrm{y}} \\
P . \text { serrulata }\end{array}$ & $2 / 2$ \\
\hline Accolade & $1 / 2$ \\
\hline Mazakura $^{\mathrm{z}}$ & $2 / 4$ \\
\hline Shirotae (WA-16) & $1 / 2$ \\
\hline Takasage $^{\mathbf{z}}$ & $2 / 4$ \\
\hline Ukon $(\mathrm{WA}-20)^{\mathrm{y}}$ & $1 / 2$ \\
\hline Yedozakura & $1 / 2$ \\
\hline $\begin{array}{l}P . \text { subhirtella cv. WA- } 19 \\
P . \text { avium } \times P \text {. fruticosa }\end{array}$ & $1 / 2$ \\
\hline cv. G8953 & $2 / 4$ \\
\hline$P$. mahaleb $\times P$. avium & \\
\hline $\mathrm{M} \times \mathrm{M}-2$ & $2 / 2$ \\
\hline$M \times M-46^{y}$ & $1 / 2$ \\
\hline Milbrath & $1 / 2$ \\
\hline Prunus spp. & \\
\hline Korean Hill Cherry & $1 / 2$ \\
\hline Pink Perfection & $1 / 2$ \\
\hline
\end{tabular}

${ }^{2}$ Accessions were propagated on mazzard seedlings; all X-MLO inoculations were made on the mazzard portions of the trees.

yPlants exhibited poor vegetative growth.

'Bing' sweet cherry ( $P$. avium) trees that bore symptomatic fruit typical of X-MLO infections and had tested positive by previous hybridization assays (see procedure below). All trees were inoculated in June 1988 and again a year later. Multiple buds (three buds per tree) and repeated inoculations (in 1988 and 1989) into the mazzard rootstock parts of the trees were done because past experience had shown that the X-MLO transmission efficiency varied from year to year (J. K.U., unpublished data). The reason for such variation is unknown.

In Aug. 1989, slightly more than a year following the first inoculations, tree symp- toms were noted and scion and sucker leaves were collected and tested for X-MLO presence by the DNA hybridization (dot-blot) procedure of Kirkpatrick et al. (1987). In these assays, control preparations were either positive (X-MLO extracts) or negative (healthy extracts).

In the X-MLO assays performed in 1989 and 1990, 130 of 174 trees were infected in scions and/or rootstock. Scion leaf petioles on 49 of the 67 accessions represented assayed positive (Table 1); we therefore classified these 49 genotypes as "susceptible" to X-MLO. In contrast, repeated assays of scion extracts of 18 accessions were dot-blot negative, while rootstock suckers were positive (Table 2). Since the mazzard rootstock were infected, we concluded that these 18 accessions are resistant to the X-MLO.

On the remaining nine accessions, all scion leaves tested negative; however, rootstock suckers were absent, so these accessions may represent escapes. The negative accessions included two inoculated trees each of $P$. $a v$ ium cv. Angela, P. fruticosa Pall. cv. FR-I, $P$. mahaleb CVs. Glenn Dale \#3 and OCR2, $P$. avium $\times P$. fruticosa CV. G456, $P$. cerasus $\times P$. fruticosa $\mathrm{CV}$. Gi 173/5, $P$. incisa $\times$ P. serrulata CV. GM 9, and Prunus spp. CVs. Autumnalis and Spire.

Canopy symptoms among the susceptible accessions consisted generally of leaf yellowing or bronzing, although a few infected accessions appeared normal (Table 1). Among resistant accessions, more than half exhibited leaf discoloration, leaf size reduction, and/or severe defoliation compared with uninoculated controls, indicating that the infected rootstock had an effect on scion vigor (Table 2)

We confined the graft inoculations to the mazzard portion of the trees because in an earlier trial, when multiple-scion buds of 'Big Burlat' were established onto a common (resistant) mahaleb rootstock and the scion shoots were inoculated with three X-MLO buds each for 2 years, only one of eight shoots had shown symptoms (J. K. U., unpublished data). Although the mahaleb rootstock supported a single 'Big Burlat' scion, the other scion shoots remained healthy. Under parallel conditions, other more susceptible cherry cultivars, such as 'Bing', developed a high incidence of X-MLO infection on inoculated shoots; again, the uninoculated shoots growing on the same rootstock remained unaffected. By establishing X-MLO infection in susceptible rootstock, we were able to cause infection of normally recalcitrant accessions, such as 'Big Burlat'.

Although replications were few (in some instances only a single tree was inoculated), positive assays were considered sufficient to indicate that 1) inoculated trees were infected and 2) susceptible or resistant responses were absolute for all test candidates as all scions were vegetative propagations from single-source trees. Therefore, based on our results, we anticipated that susceptible accessions, when used as rootstock, would behave like mazzard-rooted trees and slowly decline when infected by X-MLO. Conversely, if susceptible scions propagated on resistant accessions became X-MLO infected, and assuming host resistance was like that of $P$. mahale $b$ rootstock, the trees would decline. Also, since the $P$. avium and $P$. cerasus clones tested proved susceptible and the species in which resistance was found, e.g., P. maackii, P. mahaleb, and $P$. serrulata, are unlikely candidates for purposes of breeding for high quality cherry cultivars, the results suggest that it will be difficult to develop scion varieties resistant to X-MLO by conventional breeding methods.

\section{Literature Cited}

Gilmer, R.M. and E.C. Blodgett. 1976. X-disease. Virus diseases and noninfectious disorders of stone fruits in North America. U.S. Dept. Agr. Agr. Hdbk. 437. p. 145-155.

Kirkpatrick, B. C., D.C. Stenger, T.J. Morris and A.H. Purcell. 1987. Cloning and detection of DNA from a nonculturable plant pathogenic mycoplasmalike organism. Science 238:197200.

Richards, R.L. and L.C. Cochran. 1957. Virus and virus-like diseases of stone fruits in Utah. Utah Agr. Expt. Sta. Bul. 384. 